tance of these measurements lies in the fact that what is being studied is effectively the interaction of photons of energies much above those available from artificial sources. The most that can be said about the variation of photo-nuclear cross-section with energy at the moment is that there is no strong evidence to suggest a cross-section varying very much from $10^{-28} \mathrm{~cm} \cdot{ }^{2} /$ nucleon between 1 and 40 $\mathrm{GeV}$.

The last session was devoted to a discussion of the results of recent experiments on low-energy muons and electrons. The general impression that emerges from studies of muon decay and capture is that whereas the decay process is fairly well understood there are still some uncertainties in the explanation of the observed capture-rates. The discussion of electron interactions centred mainly around the Stanford work on nuclear sizes. One of the most interesting results of this work is the small size of the electrostatic charge core of the neutron. The interpretation of this result is not clear and the confirmation or otherwise of this result by more accurate experiments is awaited.

The conclusions to be drawn from this rather overworked Conference appear to be that there is still much to be learned about virtually every aspect of the subject. It would appear that for some time to come cosmic ray experiments are likely to be the only source of knowledge on nuclear processes at energies greater than $20 \mathrm{GeV}$.

\title{
COMMONWEALTH UNIVERSITIES' CONGRESS, 1958
}

T HE Eighth Quinquennial Congress of the Universities of the Commonwealth, the first to be held outside the United Kingdom, was held in Montreal during the first five days of September. The Congress had been preceded by a smaller conference of executive heads of the Commonwealth Universities, held in the University of Toronto during the previous week. At that conference, some useful exchanges of view took place on some current university problems. The Montreal Congress was attended by more than 400 delegates and guests, many of them accompanied by their wives. Among the guests were some twenty-four American university presidents and the members of the administrative board of the International Association of Universities. The Congress was probably the most comprehensive gathering of representatives of the university world of the British Commonwealth and the United States which has yet taken place. There was consensus of opinion that never before had so much mutual understanding been achieved, both by the sessions of the Congress and otherwise, of the general and detailed patterns of university institutions in the countries represented at the Congress. Most of the Congress sessions were held at McGill University, although one session was held in the University of Montreal. Both universities provided accommodation and lavish hospitality for the delegates and their wives.

At the opening ceremony on September 1, the delegates and guests were welcomed by Dr. Andrew Stewart, president of the University of Alberta, in his dual capacities of chairman of the Association of Universities of the British Commonwealth and president of the National Conference of Canadian Universities. The Congress was formally opened by the Right Hon. Vincent Massey, governor-general of Canada, who warned that universities to-day tread a dangerous path in increasingly accepting government money, offered because they are doing things that government wants done. "The intellectual duty of the university to remain free is," he insisted, "greater now than ever, and more difficult than ever before." The opening address of the Congress, on "Expanding Education", was then delivered by Sir Hector Hetherington, principal of the University of Glasgow, who described himself as the veteran who had attended all but one of the previous seven congresses. He referred to two new elements in the expansion of university education in all the countries represented at the Congress - that the required rate of expansion is abnormally high, and that what is wanted is not a general all-round expansion but one designed to take effect mainly in one direction, science and applied science. Sir Hector posed no new pro. blems and proffered no new solutions. He explained how the present situation had come about and what steps had been taken, and were being taken, to deal with it. He propounded the principles which, in his view, needed to be kept in mind in the expansion of professional education, if it were not to become mere vocational training, and he urged the value of keeping the humanities, together with science, at the centre of the university stage.

The first ordinary session of the Congress, on September 2, was devoted to a discussion of "Who should govern University Policy ?" In this and subsequent sessions the speakers tended to outline the procedures and philosophies applicable to their own countries, and this brought to light rather unexpected degrees of divergence but there was very little attempt at synthesis ; and the Congress formulated no general conclusions. The first speaker, Dr. V. C. Fowke (Saskatchewan), was concerned primarily with internal controls over university policy, and dealt specifically with the Canadian universities. $\mathrm{He}_{\theta}$ directed attention to two diametrically opposed concepts of university government : one, that a university ought to be a self-governing community of scholars, and the other, that it is a business enterprise which is best governed by typically corporation methods. The written constitutions of the Canadian universities tend strongly towards the latter. The allocation of funds, the determination of priorities and the selection of personnel are all the responsibilities of lay boards which have no academic representation. Usage, however, makes wide concessions to selfgovernment and it is the academic staff who determine whom they shall teach and how they shall teach, with control of examinations. They cannot have these controls without an effective voice in financial allocations. Chancellor L. A. Kimpton (Chicago), the second opening speaker, elected to defend the American practice of giving the university administrator more power, perhaps more dignity, than is usually accorded him in the British tradition. $\mathrm{He}$ pointed out that most lay boards in the American universities have only fiscal interest and power, and he claimed that the administrator should have an important role in determining policy because of the inherent 
limitations of the faculty. The defence of academic freedom is a matter to be undertaken by the university president, whose task will be the education of the public. Other functions of the president, in Dr. Kimpton's view, are: $(a)$ the protection of the academic community from pressures which might make the university unbalanced; $(b)$ to take strong remedial action with an inefficient or incompetent department, and $(c)$ the raising of funds. None of these functions can be exercised effectively by academic bodies. In the ensuing discussion, Dr. T. Alty (Rhodes University, South Africa), doubted whether the principal or vice-chancellor of a Commonwealth university had functions very different from those of the American university president. He is a key figure and must exercise an important influence on university policy. Interpretation of the university to the public is not a function of the academic staff, and is best done by members of a lay governing body. But the determination of policy should be a co-operative enterprise; academic bodies, lay boards and university president all taking a share. Sir Keith Murray (University Grants Committee), while believ. ing in solf-government, stressed the need for lay participation, in which he saw four major advantages. The lay members can bring to the university the advantages of 'corporation' methods, they can exercise a semi-judicial function and help to solve otherwise insoluble problems, they can lighten the administrative load of the academic members, and they can help to promote public confidence, especially important as universities become increasingly dependent on public funds. Other contributions were made by Sir Charles Morris (Leeds), who agreed about the value of the lay members, but thought that the modern university should give the head of an academic depart. ment an important share in policy-making; by Prof. N. K. Sidhanta (Calcutta), who directed attention to the special problems of the 35 Indian universities, with some 800,000 students, of whom more than 700,000 were taught in the numerous affiliated colleges; and by Mr. A. Hakim (East Pakistan), Prof. K. E. Bullen (Sydney), Dr. C. H. Rautenbach (Pretoria), Prof. D. V. Cowen (Cape Town), President Grayson Kirk (Columbia), Mr. W. H. Gillespie (Canterbury Agricultural College), and Dr. H. B. Thom (Stellenbosch), who discussed the respective functions of the principal, the academic staff and the lay members in the determination of policy. There was a general appreciation of the valuable role of the lay member.

At the second session of the Congress Prof. J. F. Baker (Cambridge) opened a discussion on "Engineering Education, and its Place in the University". He gave a general survey of the engineering tripos course at Cambridge, an unspecialized course covering all the main branches of engineering seience conducted in a single department of engineering. His satisfaction with the arrangements was not shared by President G. P. Harnwell (Pennsylvania) in respect of engineering education in the United States. Engineering was a latecomer among the academic disciplines; the lack of differentiation between professionalism and technicianism had operated to its disadvantage, and had hindered its recognition. Moreover, the greater emoluments and prestige of the practising engineer had adversely affected recruitment of academic staff. He thought that the closest possible association of engineering education with the universities should be maintained, and was unimpressed by the Soviet system of professional education in specialized institutes. President L. A. DuBridge (California Institu- tute of Technology) asked where else than in the university would one have engineering education, and subsequent speakers were almost unanimously in agreement, giving various reasons, such as the close affinity with other seiences, the liberalizing influence of a background of other academic disciplines and, conversely, the beneficial influence of a faculty of engineering on other faculties. A discordant note was sounded by Dr. B. V. Bowden (Manchester College of Science and Technology), who pointed out that the industrial revolution was largely due to men who had never been to a university. $\mathrm{He}$ directed attention to the dual system of engineering education in the United Kingdom (in university and college of technology), and developed the doctrine that engineering is not only a mathematical science but also an art, with design playing an important part in the work of the engineer. Mr. A. Hakim (East Pakistan) referred to the difficulty of staff recruitment, and made a plea which was echoed by other Asian speakers in other sessions, for Western assistance, by a scheme of secondment or otherwise.

The complementary theme of "Medical Education and its Place in the University" was discussed at the session on September 3. The opening speaker was Lord Adrian (Cambridge), who reminded the delegates that medical schools have often grown up out of contact with universities, and that medical students have their hospital work to prevent them from becoming too narrow-minded. He suggested that segregation in the pre-clinical period could be lessened by giving more emphasis to general scientific training which could be shared with other students. Dr. F. G. Soper (Otago) and Sir Nicholas Attygalle (Ceylon) both saw great advantage in the intermingling of medical students and those of other faculties. Dr. Soper thought it even more important that the staff should intermingle. Sir David Campbell (Aberdeen) challenged the view sometimes held that the medical curriculum is entirely vocational, and suggested that medicine is in fact the most humanizing training available in a university. The university would be much the poorer if the medical faculty were removed. His views were supported by most subsequent speakers, representing opinion in Australia, Canada, India, Malaya, Nigeria and the United Kingdom. Various aspects of the medical curriculum were discussed, and it was suggested that postgraduate studies tend to be neglected.

At a private session on September 4 the Congress discussed some current problems in Commonwealth universities, especially those in Canada, New Zealand and South Africa. The final session, on September 5, was concerned with "The Establishment of New Universities". Dr. D. W. Logan (London) outlined the part which had been played by the external degree system of the University of London in the development of the new British university institutions, both at home and in the underdeveloped parts of the Commonwealth. He directed attention to the merits and defects of the system, which he thought was unlikely to continue as the normal procedure. The principal safeguards of the quality of work in new institutions would be the external oversight of appointments and examinations. President J. L. Morrill (Minnesota) pointed out that although both Canada and the United States derived their heritage of higher learning from the British universities, the policies and procedures for the establishment of new universities in both countries represented a marked departure from the British precedents. Both nations 
had responded rapidly to the indigenous educational demands of fast-growing frontier societies and populations. "Universities are at once the catalysts and creations of a changing society." Several speakers agreed with Dr. Logan about the need in present circumstances to establish new universities. An impressive account of the principles adopted in the institution and development of seven new university institutions in the British Colonies was given by Dr. W. Adams (Rhodesia and Nyasaland). Lord Sinclair (Bristol) thought that the ultimate success of the Rhodesian experiment was of great importance to the whole British Commonwealth. Dr. C. H. Wilson (Leicester) stressed that two conditions were needed to warrant the foundation of new universities - local initiative and support, and a demand from prospective students. Dr. R. B. Madgwick (New England, N.S.W.) emphasized the weaknesses of a system of tutelage by existing universities. Dr. T. M. Advani (Bombay) referred to the remarkable demand for education in India after independence. The desire for knowledge is great, but the desire for acquiring degrees even greater. In referring to the service which universities provide for the community the Hon. P. M. Sherlock (West Indies) pointed out that the university may become a powerful competitor for limited resources. Dr. N. A. Mackenzie (British Columbia) asked whether, when it is difficult to obtain staff of adequate quality for existing institutions, it is wise to found new ones, and Dr. V. K. R. V. Rao (Delhi), after pleading for a national organization to lay down the principles on which a new institution should be established, asked : "What is a university ?" At this stage these questions proved too difficult, and the Congress disbanded.

After the Congress, executive heads of Commonwealth universities and their wives paid a week-end visit to Washington and Philadelphia as guests of the Association of American Universities. In Washington they had the honour of being received by President Eisenhower at the White House, and of being addressed by Mr. Justice Frankfurter in the Supreme Court. The other delegates were entertained by Laval University in Quebec City. After the weekend, most of the delegates set off on one or other of eleven tours for which the transport costs were provided by a generous grant from the Carnegie Corporation of New York. Members of each party were thus enabled to visit some four or five universities in Canada and the United States, hospitality being provided by the universities concerned. For many of the delegates this was the most stimulating and rewarding part of their mission, as it allowed more intimate personal contacts than had been possible at the large Congress and gave a revealing insight into the workings of a variety of university institutions in the New World.

J. W. Cook

\section{THE WORLD LAND USE SURVEY}

$\mathrm{T}$ HE World Land Use Survey owes its inspiration very largely to Prof. L. Dudley Stamp and his great achievement in carrying through in pre-war days the work and organization of the Land Utilisation Survey of Britain. A Commission, appointed at the International Geographical Congress held at Lisbon in 1949, was very impressed by the urgency of the problems of world population and world food supply and considered that "present factual knowledge is inadequate to serve as a proper foundation for schemes of improvement and development, especially in those areas which are commonly regarded as "underdeveloped" ". It proposed, therefore, a World Land Uso Survey that would record the present use of land in all parts of the world on a uniform system of classification and notation, basing the maps on field-work together with the interpretation of other material such as air photographs. It hoped that a series of maps on the scale of $1: 1,000,000$ might be published together with explanatory memoirs that would help in the understanding of the maps.

The work in different parts of the world has met with varying success. Some pilot surveys suggested that, elaborate though the land-use classification was, it often required further amplification, and sometimes modification. Aspects of the work have been taken up by Government departments, such as the Directorate of Overseas Surveys which has developed most usefully the interpretation of air photographs as a source of land-use data.

Some preliminary results are becoming available through the issuing of maps and reports. A map of Cyprus at a scale of $1: 250,000$ was published in 1956. It was based on the stereoscopic examination of 10,000 photographs and was prepared in the
Dopartment of Geography at the London School of Economics under the direction of R. R. Rawson and K. R. Sealy. The first of the Survey's 'Occasional Papers', "Land Use Studies in the Transvaal Lowland", by Dr. Monica M. Cole, of the University College of North Staffordshire and formerly of the University of the Witwatersrand, also appeared in $1956^{2}$. It was a "contribution to the study of the opportunities and difficulties inherent in the savannah environment" and laid emphasis upon the many environmental factors that challenged the area's agricultural development.

Recently, the Survey has published the first of its Regional Monographs, "A Survey of Land Use in Hong Kong and the New Territories", by Dr. Thomas R. Tregear, lecturer in geography in the University of Hong Kongs. The volume includes a coloured land-use map at a scale of $1: 80,000$ distinguishing eight types of land use: woodland, scrub, rough grassland, 'badlands' that are heavily eroded, arable, swamp, houses with gardens, and built-up areas, including camps, cemeteries and other land that is agriculturally unproductive. Hong Kong illustrates in a special way the necessity for the fullest possible use of such land as is available, with its great population (estimated at between 2 and $2 \frac{1}{2}$ millions and increasing at more than 70,000 per annum) crowded into a mere 400 square miles of the Earth's surface. There is the sharp contrast between the crowded urban areas of Hong Kong and Kowloon and the rural districts of the New Territories. Serious problems arise from the mountainous nature of much of the area and from the heavy, often torrential, rainfall which is largely responsible for the soil erosion that has created the 'badlands' of the open hillsides. 